\title{
잔존 갑상선절제술
}

부산대학교 의과대학 이비인후과학교실, 부산대학교병원 의생명연구원

천용일, 신성찬, 이병주

\section{Completion Thyroidectomy}

\section{Yongil Cheon, Sung-Chan Shin and Byung-Joo Lee}

Department of Otorhinolaryngology-Head and Neck Surgery, College of Medicine, Pusan National University and Biomedical Research Institute, Pusan National University Hospital, Busan, Korea

Completion thyroidectomy is defined as surgical removal of the remnant thyroid tissue after resection of the thyroid gland. The frequency of completion thyroidectomy varies among researchers, but is estimated to be about $5-45 \%$. Completion thyroidectomy may cause complications due to the presence of inflammation, adhesions, swelling, and scars at the surgical site due to the initial surgery. There is still controversy over the indications and timing of completion thyroidectomy. In this review, we would like to summarize the changes in indications for completion thyroidectomy and review the literature on its necessity.

Key Words: Thyroid cancer, Completion thyroidectomy, Operation

\section{서 론}

영상 장비 및 진단검사의 발달로 갑상선 질환의 진단 이 용이해지고 갑상선의 검진율이 높아지면서 갑상선암 의 빈도가 높아지고 있다. 또한 고령화 사회로 진행하면 서 갑상선암 발병률은 전 세계적으로 증가하고 있다. 미 국에서는 지난 30년간 10 만 명당 5-15명의 빈도를 보인 다고 보고하였고 ${ }^{1)}$ 국가암등록사업 연례 보고서에 따르 면 갑상선암은 2018년도 진단된 암 가운데 남녀 전체에 서 1 위를 차지하였다. ${ }^{2)}$ 그러나 갑상선암은 진단 후 엽절 제술을 또는 전절제술을 받고 방사성요오드 치료를 받 더라도 생존율은 크게 차이가 없기 때문에 비교적 안전 한 암으로 알려져 있다.")

갑상선암이 환자의 생존율에 미치는 영향은 비록 적 지만, 일부의 경우 주위 조직으로 공격적인 침범을 하거
나 전이되어 심각한 합병증을 유발하기도 한다. 일반적 으로 갑상선암은 초음파(US), 컴퓨터전산화단층촬영 (CT) 검사를 포함한 영상학적 검사와 세침흡인검사를 통해 진단을 하지만 치료방법의 선택에 있어 아직 의료 진마다 차이가 있다. 갑상선암 치료방법은 2015년 권고 된 미국 갑상선학회(ATA) 가이드라인과 NCCN (National Comprehensive Cancer Network) 가이드라인을 참고하 는 경우가 많다. ${ }^{45)}$ 국내에서도 2016년 '대한갑상선학회 갑상선결절 및 암 진료 권고안 개정안이 갑상선암의 치 료 가이드라인으로 권고되고 있지만, 실제 임상 환자에 서 적용해야 할 기준이 모호한 경우도 있고 새로운 진단 방법들도 개발되면서 현재의 가이드라인의 한계에 대한 논란이 있다. ${ }^{6}$

기능을 보존하는 최소 침습적인 술기들이 선호되면서 갑상선암 치료도 크기가 작은 경우 능동적 감시(active surveillance)를 하거나 과거에는 갑상선 전절제술을 받

Received April 20, 2021 / Revised June 14, 2021 / Accepted June 19, 2021

Correspondence: Byung-Joo Lee, MD, PhD, Department of Otorhinolaryngology-Head and Neck Surgery, College of Medicine, Pusan National University and Biomedical Research Institute, Pusan National University Hospital, 179 Gudeok-ro, Seo-gu, Busan 49241, Korea

Tel: 82-51-240-7675, Fax: 82-51-246-8668, E-mail: voiceleebj@gmail.com

Copyright (c) the Korean Thyroid Association. All rights reserved.

(1) \& This is an open-access article distributed under the terms of the Creative Commons Attribution Non-Commercial License (http://creative(c) (1) (9) This is an open-access article distributed under the terms of the Creative Commons Attribution Non-Commercial License (http://creativethe original work is properly cited. 
았을 환자들도 갑상선 엽절제술을 받기도 한다. ${ }^{78)}$ 1-4 $\mathrm{cm}$ 사이의 갑상선암에서는 갑상선 전절제술과 엽절제 술이 모두 가능하여 외과 의사들 사이에서도 논란이 되 는 경우가 있다. ${ }^{49}$ 갑상선암의 치료에서 최근의 여러 가 이드라인이 최소 수술 또는 비공격적인 치료를 시행하 는 경향으로 진행되고 있어, 전절제술에 비해 엽절제술 이 증가하는 경향을 보이고 있으며, 엽절제술 후 방사성 요오드 치료가 필요하여 남아있는 잔존 갑상선을 제거 하는 수술을 해야 하는 경우가 증가하고 있다. 잔존 갑상 선절제술은 수술했던 갑상선 부위를 다시 접근해야 하는 만큼 숙련된 술기가 필요하며 되돌이후두신경(recurrent laryngeal nerve)이나 부갑상선(parathyroid gland)의 손상 등 합병증이 잘 발생할 수 있다. 본 저자는 잔존 갑상선 절제술의 적응증과 유용성에 대해 고찰하고자 한다.

\section{본 론}

잔존 갑상선절제술은 갑상선전절제술보다 적은 갑상 선 조직을 제거한 후 남은 조직을 추가로 제거하는 수술 로 정의할 수 있으나 일반적으로는 갑상선 엽절제술 후 시행하는 반대측 엽절제술을 의미한다. ${ }^{10)}$ 잔존 갑상선절 제술은 수술 전 세포검사 결과, 초음파검사, 결절의 크기 등 여러가지 검사 결과를 고려하여 갑상선 엽절제술을 시행한 후 조직검사에서 여러가지 위험인자가 발견되어 방사성요오드 치료가 필요한 경우에 시행할 수 있고, 또 한 수술 후 남아있는 잔존 갑상선에서 수술이 필요한 갑 상선 병변이 발견된 경우에 시행할 수 있다. ${ }^{11,12)}$ 잔존 갑 상선절제술의 빈도는 5-45\%로 매우 다양하며, 기관마다 시행 빈도의 편차가 심하다. ${ }^{13,14)}$

\section{수술의 위험성과 시행 시기}

잔존 갑상선절제술은 초기 수술로 인해 수술 부위의 염증화, 유착, 부종, 흉터가 존재하기 때문에 해부학적 지표(landmark)의 소실과 박리의 어려움으로 갑상선 수 술시 보존해야 할 되돌이후두신경과 부갑상선의 손상 가능성이 높다고 알려져 있다. ${ }^{15-17)}$ 그러나 분화 갑상선 암을 대상으로 초기 수술(initial surgical procedure)과 잔 존 갑상선절제술 간의 합병증을 비교한 메타분석에서 두 그룹 사이에 합병증 발생 차이는 없는 것으로 보고되 고 있다. ${ }^{18,19)}$ 그럼에도 수술과 관련한 합병증은 외과 의 사의 숙련도에 따라 편차가 클 것으로 사료된다.

잔존 갑상선절제술을 언제 시행하는 것이 적절한지에 관하여는 논란이 있다. 일주일 이내 빠르게 재수술을 주 장하기도 하며, 3 개월 이상 늦게 시행할 것을 추천하기
도 한다. ${ }^{20,21)}$ 수술 시기에 따른 합병증 발생률이 연관성 이 없다는 연구 결과도 있지만, 잔존 갑상선절제술의 시 기에 관한 메타 연구에 따르면 3개월 미만의 비교적 이 른 시기에 수술한 군과 3 개월 이후 시행한 군 사이에 합 병증을 비교하였을 때 3 개월 이전에 수술한 군에서 유의 하게 합병증 발생 비율이 높았다. ${ }^{22}$ 잔존 갑상선절제술 의 시기는 급하게 시행할 이유가 없다면, 환자의 상태 등을 고려하여 첫 수술 후 3 개월 이후에 시행하는 것이 좋을 것으로 생각된다.

\section{잔존 갑상선 수술의 적응증}

2016년 개정된 한국의 갑상선결절에 대한 치료 가이 드라인에서는 '엽절제술을 받았으나 처음 수술 전에 갑 상선암으로 진단되었다면 갑상선 (근)전절제술이 추천 되었을 환자들에게 잔존 갑상선절제술을 권고한다'라고 되어 있고, 이러한 가이드라인은 미국 갑상선학회 (American Thyroid Association, ATA)의 가이드라인과 동일하다., ${ }^{4,6)}$ 즉 반대측 병소를 제거하고 방사성요오드 치료의 치료 효율을 높이기 위해 시행하는 것이다. 그러 나 이러한 잔존 갑상선절제술의 적응증과 유용성에 대 해서는 아직 논란이 있다.

2009년 ATA 가이드라인에는 $1 \mathrm{~cm}$ 이상의 모든 갑상 선암에서 갑상선전절제술을 권유하였으나 2015년 ATA 가이드라인에서는 1-4 $\mathrm{cm}$ 의 저위험 갑상선암은 엽절제 술을 권하고 있다. ${ }^{4)}$ 그래서 현재의 대한갑상선학회 또는 ATA 가이드라인은 과거에 비해 갑상선암이 의심되는 갑상선결절에 대한 엽절제술의 적응증이 많이 넓어졌 다. 현재의 가이드라인에 따라 엽절제술을 시행한 후 여 러가지 수술 소견 때문에 이론적으로 잔존 갑상선 수술 을 시행해야 하는 경우가 25.6-59.1\%까지 된다는 보고도 있다. ${ }^{9,23,24)} 1-2 \mathrm{~cm}$ 갑상선암에서도 엽절제술 후 이론적 으로 잔존 갑상선절제술이 필요한 경우가 36-40\%라는 보고도 있다. ${ }^{25)}$ 이러한 이유는 잔존 갑상선절제술을 시 행해야 하는 여러가지 위험 소견(risk factors)으로는 나쁜 예후를 보이는 공격적 변이 조직형(aggressive variant), 혈 관 침범(vascular invasion), 육안적 갑상선 피막 침범 (extrathyroidal extension, ETE), 심한 림프절 전이(nodal metastasis), 수술 절제연 양성(surgical margin), 반대측 갑상선의 질환(contralateral disease) 등이 있는데, 이러한 소견들 중 많은 위험 인자는 수술 전에 알 수가 없는 소 견들이다.

\section{가이드라인에 따른 잔존 갑상선절제술의 적응증 변화}

2016년에 발표된 대한갑상선학회의 권고안에서 재발 
의 위험도를 저위험군, 중간위험군, 고위험군으로 구분 하며, 이는 2010에 발표된 권고안과 동일하다. ${ }^{\circ}$ 갑상선 수술 후 방사성요오드 치료가 필요한 경우는 중간위험 군과 고위험군이다. 엽절제술 후 중간위험군과 고위험 군에 속하는 위험인자가 관찰된다면, 방사성요오드 치 료를 시행하기 위해 잔존 갑상선절제술을 시행하는 것 을 추천한다. 그리고 ATA 가이드라인도 대한갑상선학 회의 권고안의 분류와 동일하다. 대한갑상선학회나 $\mathrm{ATA}$ 에서 분류한 중간 또는 고위험군에 포함되는 위험 인자로는 갑상선 피막 침윤, 혈관 침범, 나쁜 예후를 갖 는 조직형, 5 개를 초과하는 림프절 전이, 임상적 림프절 전이, 수술 절제연 양성 등이 있다.

ATA 가이드라인에 비해 NCCN 가이드라인은 유사 점도 있지만 약간의 차이도 있다. 잔존 갑상선절제술의 수술 적응증(indication)에 대한 $\mathrm{NCCN}$ 가이드라인은 조 직학적 변이, 반대편 엽 병변, 수술 절제연, 다발성 병변, 림프절 전이, 피막 침윤, 병변 크기, 혈관 침범 등의 기준
으로 하고 있다(Table 1). ${ }^{5)}$ 그러나 이러한 기준은 매년 조금씩 변화되고 있고, 강화되고 있는 경향을 보인다. Tall 세포 변이와 같은 예후가 나쁜 조직형이 포함되었 다가 최근에서는 저분화암종만 적응증으로 포함되었다. 또한 현미경적인 수술 절제연이 포함되었다가 육안적 수술 절제연인 경우로 변경되었고, 피막 침윤도 현미경 적인 침윤보다는 육안적 침윤으로 변경되었다. 림프절 전이가 있을 경우 잔존 갑상선절제술을 권고하기도 하였 으나 육안적 림프절 전이(macroscopic nodal metastasis)가 있는 경우로 변경되었다. 그리고 육안적 림프절 전이의 기준도 매년 조금씩 변화되고 있다(Table 2). ${ }^{5}$ 2020년 $\mathrm{NCCN}$ 가이드라인에서는 $5 \mathrm{~mm}$ 초과 림프절 전이가 없 으면서 전이 개수가 5 개 미만'인 경우에는 잔존 갑상선 절제술을 하지 않는 것으로 권고하고 있지만, 가장 최근 에 개정된 2021년 NCCN 가이드라인에서는 육안적 림 프절 전이의 기준을 ' $2 \mathrm{~mm}$ 초과 림프절 전이가 없으면 서 전이 개수가 5개 미만'으로 제시해 2017년 가이드라

Table 1. NCCN 가이드라인에 따른 잔존 갑상선 엽절제술의 적응증

\begin{tabular}{|c|c|c|c|c|c|c|c|c|c|}
\hline 년도 & $\begin{array}{c}\text { 조직학적 } \\
\text { 변이 }\end{array}$ & $\begin{array}{l}\text { 반대편 } \\
\text { 엽 병변 }\end{array}$ & $\begin{array}{l}\text { 수술 } \\
\text { 절제연 }\end{array}$ & $\begin{array}{c}\text { 다발성 } \\
\text { 병변 }\end{array}$ & $\begin{array}{l}\text { 림프절 } \\
\text { 전이 }\end{array}$ & $\begin{array}{l}\text { 피막 } \\
\text { 침윤 }\end{array}$ & 크기 & $\begin{array}{l}\text { 혈관 } \\
\text { 침범 }\end{array}$ & $\begin{array}{l}\text { 림프 } \\
\text { 침범 }\end{array}$ \\
\hline 2001 & 공격적 조직변이형 & $\begin{array}{l}\text { 임상적 } \\
\text { 의심 }\end{array}$ & 양성 & $\begin{array}{c}\text { 다발성 } \\
\text { 병변 양상 }\end{array}$ & & & & & \\
\hline 2007 & $\begin{array}{l}\text { Tall세포형, } \\
\text { columnar세포형, } \\
\text { insular 암종, } \\
\text { 저분화 암종 }\end{array}$ & & 양성 & $\begin{array}{c}\text { 육안적 } \\
\text { 다발성 병변 }\end{array}$ & 양성 & 양성 & & & \\
\hline 2009 & $\begin{array}{l}\text { Tall세포형, } \\
\text { columnar세포, } \\
\text { oxyphilic 세포, } \\
\text { insular 암종, } \\
\text { 저분화 암종 }\end{array}$ & & 양성 & $\begin{array}{c}\text { 육안적 } \\
\text { 다발성 병변 }\end{array}$ & 양성 & 양성 & & & \\
\hline 2010 & $\begin{array}{l}\text { Tall세포형, } \\
\text { columnar세포형, } \\
\text { 저분화 암종 }\end{array}$ & & 양성 & $\begin{array}{c}\text { 육안적 } \\
\text { 다발성 병변 }\end{array}$ & 양성 & $\begin{array}{l}\text { 육안적 } \\
\text { 침윤 }\end{array}$ & & & \\
\hline 2011 & $\begin{array}{l}\text { Tall세포형, } \\
\text { columnar세포형, } \\
\text { 저분화 암종 }\end{array}$ & & 양성 & $\begin{array}{c}\text { 육안적 } \\
\text { 다발성 병변 }\end{array}$ & 양성 & $\begin{array}{l}\text { 육안적 } \\
\text { 침윤 }\end{array}$ & & & \\
\hline $\begin{array}{l}2012 \\
2013\end{array}$ & & & 양성 & $\begin{array}{c}\text { 육안적 } \\
\text { 다발성 병변 }\end{array}$ & 양성 & $\begin{array}{c}\text { 육안적 } \\
\text { 침윤 }\end{array}$ & $\begin{array}{l}4 \mathrm{~cm} \\
\text { 초과 }\end{array}$ & 양성 & \\
\hline $\begin{array}{c}2014- \\
2018\end{array}$ & & & 양성 & $\begin{array}{c}\text { 육안적 } \\
\text { 다발성 병변 }\end{array}$ & $\begin{array}{c}\text { 육안적 } \\
\text { 림프절 전이 }\end{array}$ & $\begin{array}{l}\text { 육안적 } \\
\text { 침윤 }\end{array}$ & $\begin{array}{c}4 \mathrm{~cm} \\
\text { 초과 }\end{array}$ & 양성 & \\
\hline 2019 & & & 양성 & $\begin{array}{l}1 \mathrm{~cm} \text { 초과 } \\
\text { 육안적 } \\
\text { 다발성 병변 }\end{array}$ & $\begin{array}{c}\text { 육안적 } \\
\text { 림프절 전이 }\end{array}$ & $\begin{array}{l}\text { 육안적 } \\
\text { 침윤 }\end{array}$ & $\begin{array}{l}4 \mathrm{~cm} \\
\text { 초과 }\end{array}$ & 양성 & \\
\hline 2020 & 저분화 암종 & $\begin{array}{c}\text { 반대편 } \\
\text { 병변 확인 }\end{array}$ & $\begin{array}{l}\text { 육안적 } \\
\text { 양성 }\end{array}$ & $\begin{array}{l}1 \mathrm{~cm} \text { 초과 } \\
\text { 육안적 } \\
\text { 다발성 병변 }\end{array}$ & $\begin{array}{c}\text { 육안적 } \\
\text { 림프절 전이 }\end{array}$ & $\begin{array}{l}\text { 육안적 } \\
\text { 침윤 }\end{array}$ & $\begin{array}{l}4 \mathrm{~cm} \\
\text { 초과 }\end{array}$ & 양성 & \\
\hline 2021 & 저분화 암종 & $\begin{array}{c}\text { 반대편 } \\
\text { 병변 확인 }\end{array}$ & $\begin{array}{l}\text { 육안적 } \\
\text { 양성 }\end{array}$ & $\begin{array}{l}1 \mathrm{~cm} \text { 초과 } \\
\text { 육안적 } \\
\text { 다발성 병변 }\end{array}$ & $\begin{array}{c}\text { 육안적 } \\
\text { 림프절 전이 }\end{array}$ & $\begin{array}{l}\text { 육안적 } \\
\text { 침윤 }\end{array}$ & $\begin{array}{l}4 \mathrm{~cm} \\
\text { 초과 }\end{array}$ & 양성 & 양성 \\
\hline
\end{tabular}


Completion Thyroidectomy

Table 2. NCCN 가이드라인에 따른 육안적 림프절 전이(macroscopic lymph node metastasis)의 기준

\begin{tabular}{ll}
\hline \multicolumn{1}{c}{ 년도 } & \multicolumn{1}{c}{ 잔존 갑상선절제술이 필요 없는 림프절 전이 } \\
\hline 2014 & 림프절 전이 개수가 5개 이하이면서 모두 크기가 $2 \mathrm{~mm}$ 미만 \\
2015,2016 & $0.5 \mathrm{~cm}$ 이상 림프절 전이가 없으면서 전이 개수가 5개 이하 \\
2017 & $2 \mathrm{~mm}$ 초과 림프절 전이가 없으면서 전이 개수가 5개 미만 \\
2018,2019 & $5 \mathrm{~mm}$ 초과 림프절 전이가 없으면서 전이 개수가 3-5개보다 작은 경우 \\
2020 & $5 \mathrm{~mm}$ 초과 림프절 전이가 없으면서 전이 개수가 5개 미만 \\
2021 & $2 \mathrm{~mm}$ 초과 림프절 전이가 없으면서 전이 개수가 5개 미만 \\
\hline
\end{tabular}

Table 3. 잔존 갑상선절제술의 찬성과 반대

\begin{tabular}{ll}
\hline \multicolumn{1}{c}{ 찬성 } & \multicolumn{1}{c}{ 반대 } \\
\hline 1. 방사성요오드 치료 가능 & 1. 생존율이나 재발률 차이 없음 \\
2. 국소 재발률 감소 & 2. 수술 합병증 발생 \\
3. 낮은 합병증 위험성 & 3. 수술에 따른 비용 \\
4. 반대편 갑상선 병변 제거 & 4. 평생 갑상선 호르몬 약물 복용 \\
5. 환자 불안감 해소 & 5. 방사성요오드 치료의 위험성 \\
& 6. 재발 후 재수술을 시행하여도 생존율에 차이가 없음
\end{tabular}

인과 동일한 기준을 권고하였다. 또한, 2021년 $\mathrm{NCCN}$ 가이드라인에서는 림프 침범(lymphatic invasion) 또는 육안적 다발성 병변(macroscopic multifocal disease)인 경 우 치료방향을 잔존 갑상선절제술을 시행할 수도 있지 만 경과 관찰도 가능하다고 제시하였다. 전체적으로 보 면 $\mathrm{NCCN}$ 가이드라인에 따르면, 가능한 제한적인 경우 에 잔존 갑상선절제술을 시행하는 것으로 매년 조금씩 권고안이 변화되는 경향이 있다.

\section{잔존 갑상선절제술의 유용성에 대한 찬성과 반대}

갑상선 엽절제술 후 방사성요오드 치료가 필요로 하 는 위험인자가 발견된 경우, 잔존 갑상선절제술을 시행 할 것인가? 아니면 경과 관찰을 할 것인가? 에 대해 아 직 논란이 있다. 앞에서 살펴본 것과 같이 가이드라인이 명확하지 않은 부분이 있고, 매년 조금씩 변화되는 경향 이 있어 실제 외과 의사 사이에서도 많은 논란이 있다. 잔존 갑상선절제술을 적극적으로 찬성하는 주장과 반대 하는 주장을 비교하면 Table 3 과 같다. ${ }^{24,26-32)}$

\section{1) 잔존 갑상선절제술을 시행하자는 주장}

방사성요오드 치료가 필요한 위험인자는 수술 전에 평가하기 힘든 경우가 많다. 최근에 개정된 대한갑상선 학회나 ATA 가이드라인에 따르면 $1-4 \mathrm{~cm}$ 크기의 갑상 선암 수술은 갑상선 엽절제술과 전절제술 모두 가능하 다. 이러한 가이드라인에 따라 갑상선 엽절제술을 시행 하는 경우 이론적으로 갑상선 엽절제술 후 잔존 갑상선 절제술이 필요한 경우는 59.1\%까지 보고하고 있다. ${ }^{9} 1-2$ $\mathrm{cm}$ 크기의 경우에도 $40 \%$ 까지 이론적으로 수술 후 잔존 갑상선절제술이 필요하다라는 보고도 있다. ${ }^{25)}$ 위험인자 가 발견되면 방사성요오드 치료가 필요하고, 방사성요 오드 치료를 시행하는 것이 향후 재발률이나 생존율에 도움이 될 것으로 생각된다. 그러나 아직 엽절제술 후 잔존 갑상선절제술을 시행하였을 경우, 생존율이 증가 한다는 연구 결과는 없지만, 일부에서 잔존 갑상선절제 술을 시행하는 경우 국소 재발이 감소한다는 보고가 있 다. ${ }^{27)}$

잔존 갑상선절제술을 시행하면 추가적인 수술이 필요 하지만, 수술의 위험성이 높지 않고, 반대편 갑상선엽에 서 발생하는 다발성 병변을 같이 제거할 수 있다는 장점 이 있다. 방사성요오드 치료가 필요한 경우이나 잔존 갑 상선절제술 없이 경과 관찰 만을 시행하는 것은 환자에 게 재발에 대한 불안감을 줄 수도 있다. 이러한 불안감을 감소시키기 위한 환자, 내과 의사, 외과 의사, 핵의학과 의사들로 이루어진 다학제 진료를 통해 이러한 불안감 을 해소하면서 적절한 치료방법을 선택하는 것이 중요 하다.

\section{2) 잔존 갑상선절제술을 반대하는 주장}

갑상선 엽절제술 후 중간 위험군으로 분류된 환자에 서 전절제술을 시행하여도 재발률이나 생존율에 차이가 없다. ${ }^{3,33,34)}$ 그래서 잔존 갑상선절제술의 유용성에 대해 논란이 있다. 이러한 연구는 주로 후향적으로 시행한 연 구로 선택 편의(selection bias)가 있을 것으로 생각되며, 향후 잘 계획된 무작위 연구가 필요할 것으로 생각된다. 
또한 잔존 갑상선절제술을 시행하는 경우 반회후두신경 손상이나 부갑상선기능저하증과 같은 수술 위험성이 있 고, 수술에 따른 비용이 발생한다. 갑상선 엽절제술 후에 도 갑상선 약을 복용할 수 있지만, 잔존 갑상선절제술을 시행하는 경우 평생 갑상선약을 복용해야 한다. 잔존 갑 상선절제술을 받아야 하는 주요한 근거인 방사성요오드 치료의 안전성과 유용성에 대해서도 논란이 있을 수 있 다. 방사성요오드 치료 자체의 부작용 및 2 차 암의 위험 성도 고려하여야 한다. ${ }^{35)}$ 또한 재발한 후에 갑상선절제 술을 시행하여도 생존율에 차이가 없을 수 있다는 주장 도 있다.

\section{결 론}

갑상선 엽절제술 후 방사성요오드 치료하여 잔존 갑 상선절제술을 시행하여도 생존율이 향상되거나 재발률 이 감소한다는 연구 결과는 아직 없다. 최근에 개정된 갑상선암 치료 가이드라인은 갑상선암 수술의 적응증과 범위를 최소화하려는 경향이 있다. 이러한 전체적인 경 향과 유사하게 잔존 갑상선절제술의 적응증도 점차 제 한적으로 시행하는 방향으로 가이드라인이 변화되는 경 향이 있다. 잔존 갑상선절제술의 적응증에 대한 논란이 있지만, 환자, 내분비내과 의사, 외과 의사, 핵의학과 의 사로 구성된 다학제 진료를 통해 잔존 갑상선절제술의 장단점에 대한 설명을 통해 적절한 치료방침을 결정하 는 것이 필요할 것으로 생각된다.

중심 단어: 갑상선암, 잔존 갑상선절제술, 수술.

\section{Acknowledgments}

본 연구는 2021년도 부산대학교병원 임상연구비 지원 으로 이루어졌음.

\section{Conflicts of Interest}

No potential conflict of interest relevant to this article was reported.

\section{Orcid}

Yongil Cheon: https://orcid.org/0000-0003-0288-0542

Sung-Chan Shin: https://orcid.org/0000-0003-2329-0648

Byung-Joo Lee: https://orcid.org/0000-0001-7091-6688

\section{References}

1) Kuo LE, Angell TE, Pandian TK, Moore AL, Alexander EK, Barletta JA, et al. Completion thyroidectomy is less common following updated 2015 American Thyroid Association guidelines. Ann Surg Oncol 2021;28(1):484-91.

2) Korea Central Cancer Registry, National Cancer Center. Annual report of cancer statistics in Korea in 2018, Ministry of Health and Welfare, 2020.

3) Adam MA, Pura J, Gu L, Dinan MA, Tyler DS, Reed SD, et al. Extent of surgery for papillary thyroid cancer is not associated with survival: an analysis of 61,775 patients. Ann Surg 2014;260(4):601-5; discussion 5-7.

4) Haugen BR, Alexander EK, Bible KC, Doherty GM, Mandel SJ, Nikiforov YE, et al. 2015 American Thyroid Association management guidelines for adult patients with thyroid nodules and differentiated thyroid cancer: the American Thyroid Association guidelines task force on thyroid nodules and differentiated thyroid cancer. Thyroid 2016;26(1):1-133.

5) National Comprehensive Cancer Network (NCCN). NCCN clinical practive guidelines in oncology: thyroid carcinoma. [cited June 22, 2021]. Available from: http://www.nccn.org/professionals/ physician_gls/default.aspx.

6) Yi KH, Lee EK, Kang H-C, Koh Y, Kim SW, Kim IJ, et al. 2016 revised Korean Thyroid Association management guidelines for patients with thyroid nodules and thyroid cancer. Int J Thyroidol 2016;9(2):59-126.

7) Kim TY, Shong YK. Active surveillance of papillary thyroid microcarcinoma: a mini-review from Korea. Endocrinol Metab (Seoul) 2017;32(4):399-406.

8) Perros P, Boelaert K, Colley S, Evans C, Evans RM, Gerrard $\mathrm{Ba} \mathrm{G}$, et al. Guidelines for the management of thyroid cancer. Clin Endocrinol (Oxf) 2014;81 Suppl 1:1-122.

9) Murthy SP, Balasubramanian D, Subramaniam N, Nair G, Babu MJC, Rathod PV, et al. Prevalence of adverse pathological features in 1 to $4 \mathrm{~cm}$ low-risk differentiated thyroid carcinoma. Head Neck 2018;40(6):1214-8.

10) Eroglu A, Berberoglu U, Buruk F, Yildirim E. Completion thyroidectomy for differentiated thyroid carcinoma. J Surg Oncol 1995;59(4):261-6; discussion 6-7.

11) Makay O, Unalp O, Icoz G, Akyildiz M, Yetkin E. Completion thyroidectomy for thyroid cancer. Acta Chir Belg 2006;106(5):528-31.

12) Varaldo E, Ansaldo GL, Assalino M, Massobrio A, Torre GC, Borgonovo G. Completion thyroidectomy for differentiated thyroid cancer (results in a consecutive series of 68 patients). Acta Chir Belg 2012;112(1):40-3.

13) Shaha AR, Michael Tuttle R. Completion thyroidectomy-indications and complications. Eur J Surg Oncol 2019;45(7):1129-31.

14) Sawant R, Hulse K, Sohrabi S, Yeo JCL, Pal K, Gibb FW, et al. The impact of completion thyroidectomy. Eur J Surg Oncol 2019;45(7):1171-4.

15) Hardman JC, Smith JA, Nankivell P, Sharma N, Watkinson JC. Re-operative thyroid surgery: a 20-year prospective cohort study at a tertiary referral centre. Eur Arch Otorhinolaryngol 
Completion Thyroidectomy

2015;272(6):1503-8.

16) Vaiman M, Nagibin A, Olevson J. Complications in primary and completed thyroidectomy. Surg Today 2010;40(2):114-8.

17) Lefevre JH, Tresallet C, Leenhardt L, Jublanc C, Chigot JP, Menegaux F. Reoperative surgery for thyroid disease. Langenbecks Arch Surg 2007;392(6):685-91.

18) Mirghani H, Altedlawi Albalawi IA 2nd. The ongoing debate regarding completion thyroidectomy versus primary thyroid surgery for low and intermediate differentiated thyroid carcinoma: a meta-analysis. Cureus 2020;12(12):e12033.

19) Gulcelik MA, Dogan L, Akgul GG, Guven EH, Ersoz Gulcelik N. Completion thyroidectomy: safer than thought. Oncol Res Treat 2018;41(6):386-90.

20) Walgenbach S, Junginger T. Is the timing of completion thyroidectomy for differentiated thyroid carcinoma prognostic significant?. Zentralbl Chir 2002;127(5):435-8.

21) Glockzin G, Hornung M, Kienle K, Thelen K, Boin M, Schreyer AG, et al. Completion thyroidectomy: effect of timing on clinical complications and oncologic outcome in patients with differentiated thyroid cancer. World J Surg 2012;36(5):1168-73.

22) Bin Saleem R, Bin Saleem M, Bin Saleem N. Impact of completion thyroidectomy timing on post-operative complications: a systematic review and meta-analysis. Gland Surg 2018;7(5): 458-65.

23) Guo MY, Wiseman JJ, Wiseman SM. Current surgical treatment of intermediate risk differentiated thyroid cancer: a systematic review. Expert Rev Anticancer Ther 2021;21(2): 205-20.

24) Kluijfhout WP, Pasternak JD, Drake FT, Beninato T, Shen WT, Gosnell JE, et al. Application of the new American Thyroid Association guidelines leads to a substantial rate of completion total thyroidectomy to enable adjuvant radioactive iodine. Surgery 2017;161(1):127-33.

25) Kluijfhout WP, Pasternak JD, Lim J, Kwon JS, Vriens MR, Clark $\mathrm{OH}$, et al. Frequency of high-risk characteristics requiring total thyroidectomy for $1-4 \mathrm{~cm}$ well-differentiated thyroid cancer. Thyroid 2016;26(6):820-4.

26) Ruel E, Thomas S, Dinan M, Perkins JM, Roman SA, Sosa
JA. Adjuvant radioactive iodine therapy is associated with improved survival for patients with intermediate-risk papillary thyroid cancer. J Clin Endocrinol Metab 2015;100(4):1529-36.

27) Liu J, Zhang Z, Huang H, Xu S, Liu Y, Liu S, et al. Total thyroidectomy versus lobectomy for intermediate-risk papillary thyroid carcinoma: a single-institution matched-pair analysis. Oral Oncol 2019;90:17-22.

28) Riju J, Thomas S, Anila KR. Completion thyroidectomy in differentiated thyroid malignancy-a prospective analysis. Indian J Surg Oncol 2019;10(1):130-4.

29) Ibrahim B, Forest VI, Hier M, Mlynarek AM, Caglar D, Payne RJ. Completion thyroidectomy: predicting bilateral disease. J Otolaryngol Head Neck Surg 2015;44:23.

30) Li YJ, Wang YZ, Yi ZB, Chen LL, Zhou XD. Comparison of completion thyroidectomy and primary total surgery for differentiated thyroid cancer: a meta-analysis. Oncol Res Treat 2015;38(10):528-31.

31) Al-Qurayshi Z, Shama MA, Randolph GW, Kandil E. Minimal extrathyroidal extension does not affect survival of well-differentiated thyroid cancer. Endocr Relat Cancer 2017; 24(5):221-6.

32) Lang $\mathrm{BH}$, Shek TW, Wan KY. The significance of unrecognized histological high-risk features on response to therapy in papillary thyroid carcinoma measuring 1-4 cm: implications for completion thyroidectomy following lobectomy. Clin Endocrinol (Oxf) 2017;86(2):236-42.

33) Nixon IJ, Ganly I, Patel SG, Palmer FL, Whitcher MM, Tuttle RM, et al. Thyroid lobectomy for treatment of well differentiated intrathyroid malignancy. Surgery 2012;151(4):571-9.

34) Matsuzu K, Sugino K, Masudo K, Nagahama M, Kitagawa $\mathrm{W}$, Shibuya H, et al. Thyroid lobectomy for papillary thyroid cancer: long-term follow-up study of 1,088 cases. World J Surg 2014;38(1):68-79.

35) Sawka AM, Thabane L, Parlea L, Ibrahim-Zada I, Tsang RW, Brierley JD, et al. Second primary malignancy risk after radioactive iodine treatment for thyroid cancer: a systematic review and meta-analysis. Thyroid 2009;19(5):451-7. 